\title{
Detection of CD33 expression on monocyte surface is influenced by phagocytosis and temperature
}

\author{
Nittiya Suwannasom ${ }^{1,2}$, Kathrin Smuda ${ }^{1}$, Chiraphat Kloypan ${ }^{1,3}$, Waraporn Kaewprayoon ${ }^{1,5}$, \\ Nuttakorn Baisaeng ${ }^{4}$, Chanchai Boonla ${ }^{6}$, Radostina Georgieva ${ }^{1,7}$ and Hans Bäumler ${ }^{1}$ \\ ${ }^{1}$ Charité - Universitätsmedizin Berlin, Institute of Transfusion Medicine, Berlin, Germany \\ ${ }^{2}$ University of Phayao, School of Medical Sciences, Phayao, Thailand \\ ${ }^{3}$ University of Phayao, School of Allied Health Sciences, Phayao, Thailand \\ ${ }^{4}$ University of Phayao, School of Phamaceutical Sciences, Phayao, Thailand \\ ${ }^{5}$ Payap University, Department of Pharmacy, Chiang Mai, Thailand \\ ${ }^{6}$ Chulalongkorn University, Department of Biochemistry, Bangkok, Thailand \\ 7 Trakia University, Medical Faculty, Department of Medical Physics, Biophysics and Radiology, Stara Zagora, Bulgaria
}

\begin{abstract}
CD33 is a myeloid-associated marker and belongs to the sialic acid-binding immunoglobulin (Ig)-like lectin (Siglec) family. Such types of receptors are highly expressed in acute myeloid leukemia, which could be used in its treatment. CD33 shows high variability in its expression levels with still unknown reasons. Here, we investigated the CD33 expression of monocytes in human blood samples processed at different temperatures and in dependence on their phagocytic activity against opsonized Escherichia coli. The samples were stained by fluorescently labelled anti-human CD14 to specify the monocyte population, anti-human CD33 antibodies to evaluate CD33 expression and analyzed by flow cytometry and confocal laser scanning microscopy. In blood samples kept at $37^{\circ} \mathrm{C}$ or first pre-chilled at $0^{\circ} \mathrm{C}$ with subsequent warming up to $37^{\circ} \mathrm{C}$, the percentage of CD33-positive monocytes as well as their relative fluorescence intensity was up-regulated compared to samples kept constantly at $0^{\circ} \mathrm{C}$. After exposure to E. coli the CD33 relative fluorescence intensity of the monocytes activated at $37^{\circ} \mathrm{C}$ was 3 to 4 times higher than that of those cells kept inactive at $0^{\circ} \mathrm{C}$. Microscopic analysis showed internalisation of CD33 due to its enhanced expression on the surface followed by engulfment of E. coli.
\end{abstract}

Key words: CD33 - Expression — Pre-analytical conditions - Internalisation

\section{Introduction}

Clusters of differentiation (CDs) are receptors or surface markers used to classify cell type and maturation stage of leukocytes as well as other associated cells by staining with specific antibodies. CD antigens as receptors and ligands accomplish a variety of critical functions in the immune response such, cell signal cascades and cell adhesion (Zola et al. 2007). In certain circumstances CD antigens are expressed in some specific developmental stage or under some environmental and experimental conditions with different

Correspondence to: Hans Bäumler, Charité - Universitätsmedizin Berlin, Institute of Transfusion Medicine, 10117 Berlin, Germany E-mail: hans.baeumler@charite.de expression level. Consequently, the patterns of expression of cell surface CD antigens are promising goals for diagnostic and therapeutic clinical applications and research of different types of diseases such as cardiovascular disease, cancer, immunotherapy, and drug targeting (Golay et al. 2000; Woolfson et al. 2006; Sakamoto et al. 2009).

CD33, a $67 \mathrm{kDa}$ type I transmembrane cell surface glycoprotein receptor, belongs to the sialic acid-binding immunoglobulin-like lectins (Siglecs, Siglec-3) family. Structurally, CD33 contains a V-set domain, a C2-set domain, and a transmembrane region followed by immunoreceptor tyrosine-based inhibitory motif (ITIM) and ITIM-like motif (Laszlo et al. 2014a). CD33 is expressed at high level on monocytes and macrophages, but at low level on mature granulocytes (Andrew et al. 1983; Freeman 
et al. 1995). Besides, CD33 is an accepted surface marker to identify monocytes (Terstappen et al. 1990). However, despite the crucial role of CD33, little is known about its function in myeloid cells, except that it may acts as an inhibitory molecule on the innate immune cells to mediate the cell-cell interaction and to inhibit normal functions through a reducing effect on tyrosine kinase-driven signaling (Paul et al. 2000; Crocker and Redelinghuys 2008). Recent studies have shown that antibodies specific to CD33 possessed an ability to activate cytokine secretion by monocytes, suggesting a potential role of CD33 molecule in the cytokine responses of the immune system (Lajaunias et al. 2005). In addition, it has been noted that CD33 acts as an inhibitory factor on dendritic cell differentiation (Ferlazzo et al. 2000). Dendritic cells are antigen presenting cells which mainly interact with the adaptive immune system whereas monocyte derived macrophages are part of the innate immune response. CD33 up-regulation might inhibit dendritic cell differentiation when faced with a high number of pathogens (such as opsonized bacteria) to ensure the availability of these cells for phagocytosis and elimination of these pathogens. Previous studies have also shown that up-regulation of CD33 in chronic obstructive pulmonary disease (COPD) patients was higher than that in the normal control group; however, no statistically significant differences were found between control group and patients (Zhang et al. 2013).

Moreover, the knowledge of CD33 expression levels could offer promising therapeutic strategies for certain diseases. Previous studies reported a correlation between the expression of CD33 and Alzheimer's disease and that the inhibition of CD33 may be a promising therapeutic target for this disease (Jiang et al. 2014; Hooli and Tanzi 2016). Furthermore, the level of CD33 has been shown to be associated with the disease prognostic factors for acute myeloid leukemia (AML) and may thus serve as an attractive candidate for antibodybased therapeutic (Cowan et al. 2013; Krupka et al. 2014; Laszlo et al. 2014b).

It is well established that several factors such as purification methods, storage and incubation temperature, or specimen age and anticoagulants affect the antigen expression levels of certain cell surface proteins of leukocytes. Some leukocyte surface markers (CD11a,b,c, CD18 and CD35) can be increased by handling procedures and temperature changes (Fearon and Collins 1983; Miller et al. 1987; Forsyth and Levinsky 1990; Lundahl et al. 1995), whereas these factors have no effect on other antigens for example CD15s, CD44, or CD62L (Youssef et al. 1995). Nevertheless, it was also reported that preparation procedure at higher temperature decreased the expression of CD62L (Stibenz et al. 1994; Lundahl et al. 1995).

Some studies found that besides temperature, phagocytosis may also influence the expression of antigens, suggesting that these changes may be caused by inflammation due to immunological response following phagocytic activity. For instance, the expression of CD11b and CD35 is increased (Repo et al. 1995), while CD64 and CD88 were not altered (Furebring et al. 2004) but CD14 is decreased in lipopolysaccharide (LPS)-stimulated monocytes (Jorgensen et al. 2001). Hence, the knowledge about up- or down-regulation of surface markers might be useful for therapeutic concepts.

To date, only a few research reports give detailed information on sample handling for the investigation of CD33 expression. The influence of temperature and phagocytosis on up- or down-regulation of CD33 expression should be clearly understood to support existing or future diagnostic and therapeutic approaches. Therefore, in the current study we investigated the effect of temperature as well as the presence of phagocytosis activating agents, E. coli, on the expression level of monocytes.

\section{Materials and Methods}

\section{Materials}

Phosphate buffered saline (PBS) pH 7.4 stock solution $(10 \times)$ was purchased from Fisher Scientific (Pittsburgh, PA). $\mathrm{NH}_{4} \mathrm{Cl}, \mathrm{NaHCO}_{3}$, EDTA were purchased from Sigma. PerCP/Cyanine5.5 anti-human CD33 Antibody, Mouse IgG1, $\kappa$, clone WM53 and clone P67.6 were purchased from BioLegend (San Diego, CA). Isotype control (non-specific isotype control antibody) PerCP/Cyanine5.5 Mouse IgG1, $\kappa$, Isotype Ctrl Antibody was purchased from BioLegend (San Diego, CA). Alexa Fluor ${ }^{\oplus} 88$ anti-human CD14 antibody (Clone M5E2) was purchased from BD Pharmingen (San Diego, CA). Lithium heparin vacutainers (34 I.U.) were purchased from Becton Dickinson (Plymouth, UK). Phagotest $^{\mathrm{TM}}$ and Phagoburst ${ }^{\mathrm{TM}}$ kit were purchased from Glycotope-Biotechnology (Heidelberg, Germany). All chemicals used for experimental work were of analytical grade.

\section{Blood collection, preparation and leukocyte staining}

Freshly withdrawn venous blood anticoagulated by lithium heparin was collected from healthy volunteers. Informed consent was obtained from all donors in written form. The blood samples were withdrawn in accordance with the transfusion law of Germany. The use of donor blood samples for scientific purposes was approved by the ethics committee of the Charité - Universitätsmedizin Berlin (\# EA1/137/14). Two tubes of blood were collected at the same time: one sample was immediately transferred to an ice bath $\left(0^{\circ} \mathrm{C}\right)$, and the other sample was taken into a water bath and kept at $37^{\circ} \mathrm{C}$. 
Figure 1 shows the experimental design. The samples were handled in three different ways. Whole blood was aliquoted into $50 \mu \mathrm{l}$ samples in three separate tubes. One tube was maintained always on ice $\left(0^{\circ} \mathrm{C}\right)$. A second tube was chilled for $10 \mathrm{~min}$ at $0^{\circ} \mathrm{C}$ and then transferred to a water bath for $10 \mathrm{~min}$ at $37^{\circ} \mathrm{C}$. The third tube was placed immediately and maintained in the water bath at $37^{\circ} \mathrm{C}$.

At the end of the incubation period, all samples were placed in the ice-bath, and washed with ice-cold PBS. The cells were re-suspended and then incubated with anti-CD14 and anti-CD33 antibody using concentrations suggested by the manufacturer with a concentration of $16 \mu \mathrm{g} / \mathrm{ml}$ for $30 \mathrm{~min}$ at $0^{\circ} \mathrm{C}$ in darkness. Erythrocytes were lysed with ammonium chloride solution $\left(155 \mathrm{mM} \mathrm{NH}_{4} \mathrm{Cl}, 12 \mathrm{mM}\right.$ $\mathrm{NaHCO}_{3}, 0.1 \mathrm{mM}$ EDTA) for $15 \mathrm{~min}$. The cells were washed twice and re-suspended in ice-cold PBS and then immediately analysed by flow cytometry

\section{Phagocytosis of bacteria at different temperatures}

\section{Phagocytosis of non-labeled E. coli}

Opsonized E. coli $\left(1-2 \times 10^{9}\right.$ bacteria per ml, Phagoburst $\mathrm{kit}^{\mathrm{TM}}$ ) was used to examine the engulfment of bacteria. The samples were handled in the same way as in the temperature experiments. One tube was maintained always on ice the other tube was pre-chilled for $10 \mathrm{~min}$ and then transferred from the ice bath to the water bath $\left(37^{\circ} \mathrm{C}\right)$ and warmed up for $10 \mathrm{~min}$ at $37^{\circ} \mathrm{C}$ after adding $10 \mu \mathrm{l}$ of non-labeled opsonized E. coli. In parallel, the samples kept at $37^{\circ} \mathrm{C}$ were incubated for 10 min with $10 \mu \mathrm{l}$ of $E$. coli.

After $10 \mathrm{~min}$, engulfment and uptake were stopped by cooling to $0^{\circ} \mathrm{C}$ and washing with ice cold PBS. Subsequently, cells were stained with anti-CD14 and anti-CD33 antibody with a concentration of $16 \mu \mathrm{g} / \mathrm{ml}$ for $30 \mathrm{~min}$ at $0^{\circ} \mathrm{C}$ in darkness, followed by erythrocyte lysis using ammonium chloride lysing solution for $15 \mathrm{~min}$. Cells were washed and re-suspended in PBS and immediately analysed with the flow cytometer.

\section{Phagotest of Fluorescein isothiocyanate (FITC)-labeled} opsonized E. coli

Phagotest ${ }^{\mathrm{TM}}$ kit was used to confirm healthy phagocytotic activity of monocytes. Manufacturer's instructions were partially modified: all reactions were performed with half of the volume, samples were incubated at two different temperature conditions, lysing solution was changed to ammonium chloride lysing solution, and DNA was not stained.

\section{Internalisation of CD33 during phagocytosis}

To examine the internalisation of CD33, $50 \mu$ l of blood were mixed with anti-CD14 and anti-CD33 antibody with a final

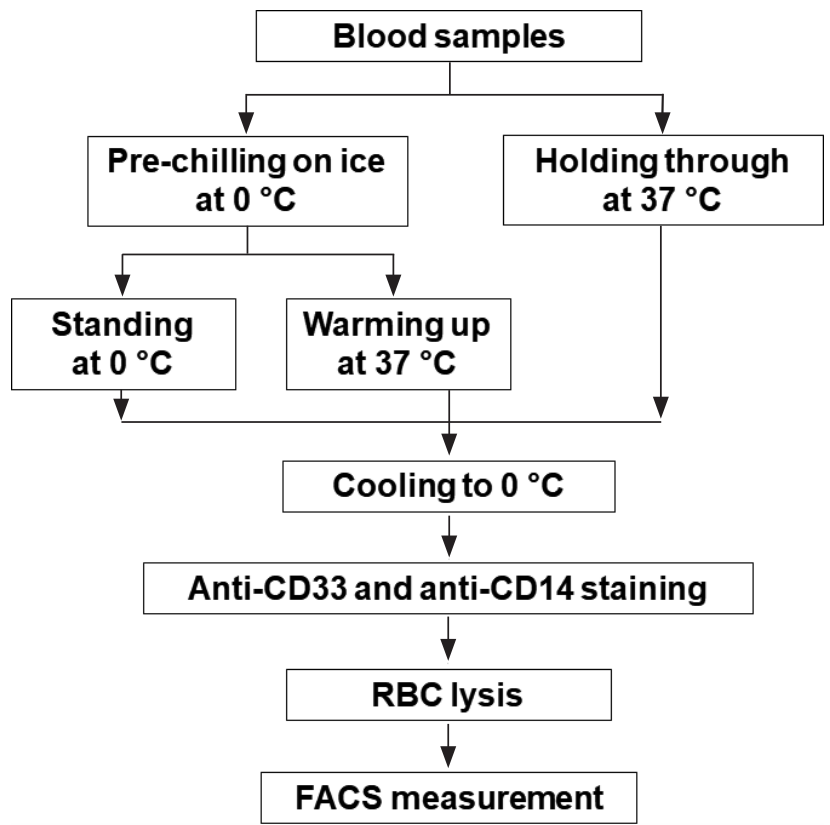

Figure 1. Schematic experimental design. Two sets of three tubes with whole blood from the test subject were handled as followed: two $50 \mu \mathrm{l}$ aliquots of whole blood from ice bath $\left(0^{\circ} \mathrm{C}\right)$ cooler were either maintained always on ice or after pre-chilling warmed up to $37^{\circ} \mathrm{C}$. One $50 \mu \mathrm{l}$ aliquot of whole blood from water bath $\left(37^{\circ} \mathrm{C}\right)$ was always prepared throughout at $37^{\circ} \mathrm{C}$.

staining concentration of $16 \mu \mathrm{g} / \mathrm{ml}$ for $30 \mathrm{~min}$ at $0^{\circ} \mathrm{C}$ in darkness. Then $10 \mu$ lopsonised E. coli $\left(1-2 \times 10^{9}\right.$ bacteria per $\left.\mathrm{ml}\right)$ was added and incubated at $37^{\circ} \mathrm{C}$ or an ice bath $\left(0^{\circ} \mathrm{C}\right)$ for negative controls for $10 \mathrm{~min}$.

After $10 \mathrm{~min}$, engulfment and uptake were stopped by cooling to $0^{\circ} \mathrm{C}$ and washing with ice cold PBS. Subsequently, ammonium chloride lysing solution was added and incubated on ice for $15 \mathrm{~min}$. Cells were washed and re-suspended in PBS and immediately analysed with the flow cytometry.

\section{Flow cytometry}

The leukocytes were analysed by flow cytometry (FACSCanto II, Becton and Dickinson, Franklin Lakes, NJ, U.S.A.) after diluting in PBS with ratio of 1:40 (Tölle et al. 2010; Zhao et al. 2017). 10,000 total events from each tube were collected. Monocytes, granulocytes, and lymphocytes were identified based on their forward and sideward scatter (FSC and SSC, resp.) characteristics. Then, the additional staining with anti-CD14 was gated out to identify monocyte population. Subsequently, positively stained CD33 cells were determined in the PerCP/Cy5.5 fluorescence channel as relative median fluorescence intensity (RFI). Data were analysed using the FlowJo v10 software (Tree Star, Ashland, OR). 


\section{Confocal laser scanning microscopy (CLSM)}

Non-labeled (control), anti-CD14, and anti-CD33 labeled samples were investigated using a confocal laser scanning microscope (CLSM; ZeissLSM 510 meta, Zeiss MicroImaging $\mathrm{GmbH}$, Jena, Germany) equipped with a $100 \times$ oil immersion objective, with a numerical aperture of 1.3. Images of the samples were prepared in transmission and fluorescence mode with fluorescence excitation at $488 \mathrm{~nm}$ for both FITC as well as PerCP/Cy5.5, a band pass filter (513-556 nm) for FITC emission and a $650 \mathrm{~nm}$ long pass emission filter for PerCP/Cy5.5. Cells stained with anti-CD33 and anti-CD14 antibodies were identified as monocytes. The fluorescence distribution inside the monocytes before and after stimulation with $E$. coli was investigated by analysis of z-stacks applying the LSM 510 software.

\section{Statistical analysis}

Analyses and graphs were performed using GraphPad Prism 6 software (GraphPad, San Diego, CA). Statistical analysis was performed using one-way analysis of variance followed by the Tukey multiple comparison test to determine the significance of particular comparisons. Two-way analysis of variance was used to determine significance in temperature and phagocytosis factors. Significance was defined as $p$-value $<0.05$, and is presented as ${ }^{\star} p<0.05,{ }^{* *} p<0.01$, or ${ }^{* * *} p<0.0001$.

\section{Results}

The monocyte, granulocyte and lymphocyte populations in all samples could be clearly identified by flow cytometry in the SSC/FSC dot plots. The monocytes are then defined by sequential gating on all CD14-positive leukocytes in light scatter plots. More than ninety percent of the CD-33 positive were CD14-positive cells. The CD33 labeling was highly specific for the monocytes (Fig. 2).

\section{Temperature-dependent influence in CD33 expression on monocyte surface}

The influence of temperature treatment on CD33 expression of monocytes was investigated as shown in Figure 1. Monocytes maintained at $0^{\circ} \mathrm{C}$ at all stages of preparation were defined as the reference levels of expression of CD33.

Monocytes that were pre-chilled and subsequently warmed up and those maintained at $37^{\circ} \mathrm{C}$ throughout their preparation showed a significantly higher RFI of CD33 compared to the reference cells maintained at $0^{\circ} \mathrm{C}$. There was slightly lower, but not significantly different expression level, for cells cooled at $0^{\circ} \mathrm{C}$ and subsequently warmed to $37^{\circ} \mathrm{C}$ than those cells maintained at $37^{\circ} \mathrm{C}$ at all stages of preparation (Fig. 3A, solid bars).

These results were independent on the used monoclonal antibody against CD33 clone WM53 and P67.6, respectively.
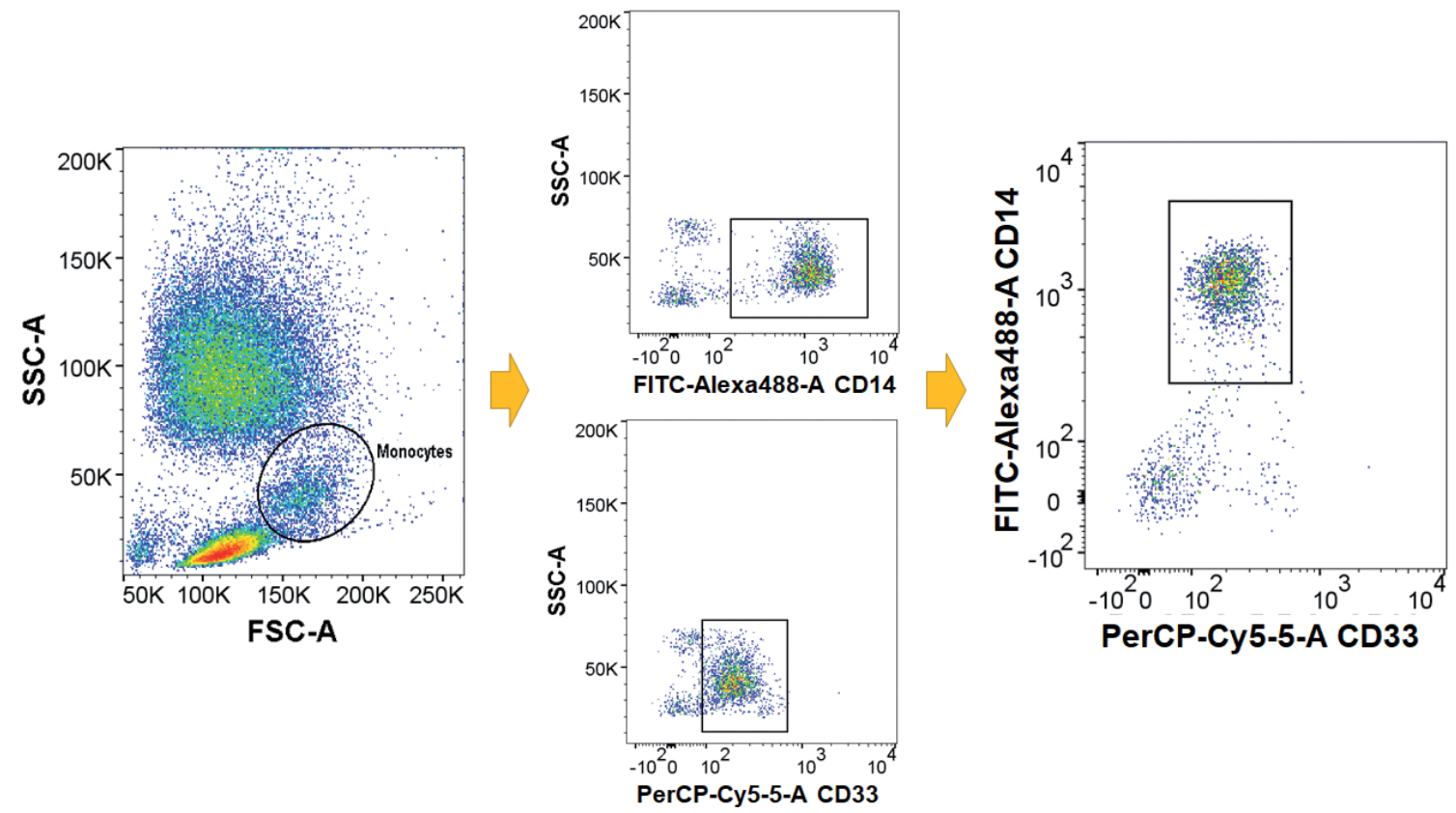

Figure 2. Gating of the cells, CD14 and CD33 labeled cells. Three groups of cells were identified based on their forward scatter (FSC) and side scatter (SSC). By incubating these cells with Alexa Fluor 488 anti-CD14 and PerCP/Cy5.5-anti-CD33, monocytes can be identified and relative median fluorescence intensity (RFI) was interpreted as positive for CD33 expression from the sample held at $0^{\circ} \mathrm{C}$. 
Figure 3C shows the histograms of four different sample types at the investigated temperatures. Isotype staining as well as samples without staining provide the same very low fluorescence intensity under all conditions. The fluorescence intensities of the stained samples (clone WM53 and clone P67.6) show no significant differences.
Changes in CD33 expression due to phagocytosis of E. coli

The ability of monocytes to perform phagocytosis was tested for each donor in parallel applying the standard procedure of FITC-labeled E. coli as recommended in the Phagotest ${ }^{\mathrm{TM}}$ kit instructions. Percentages of phagocytizing monocytes and
A

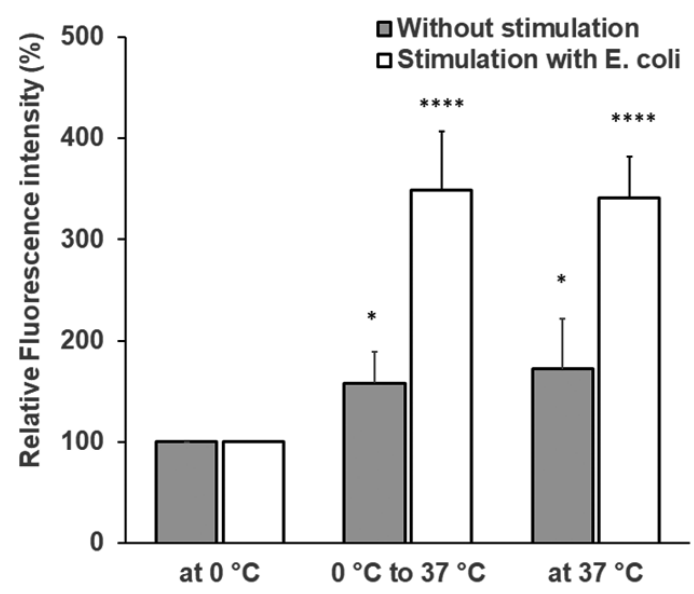

B

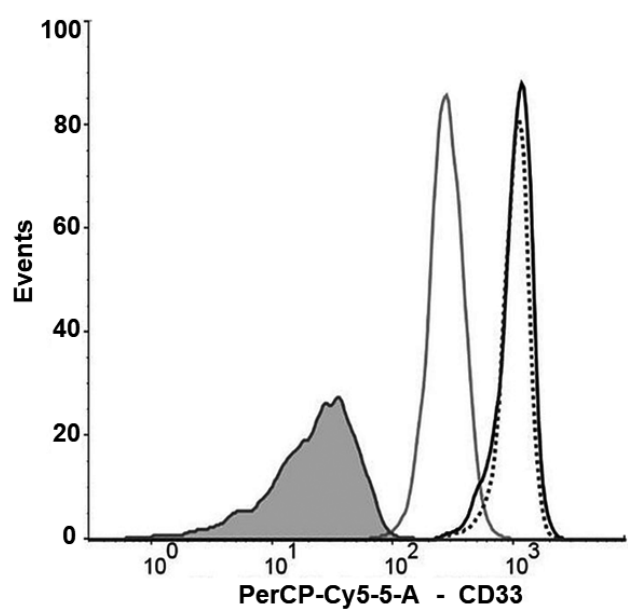

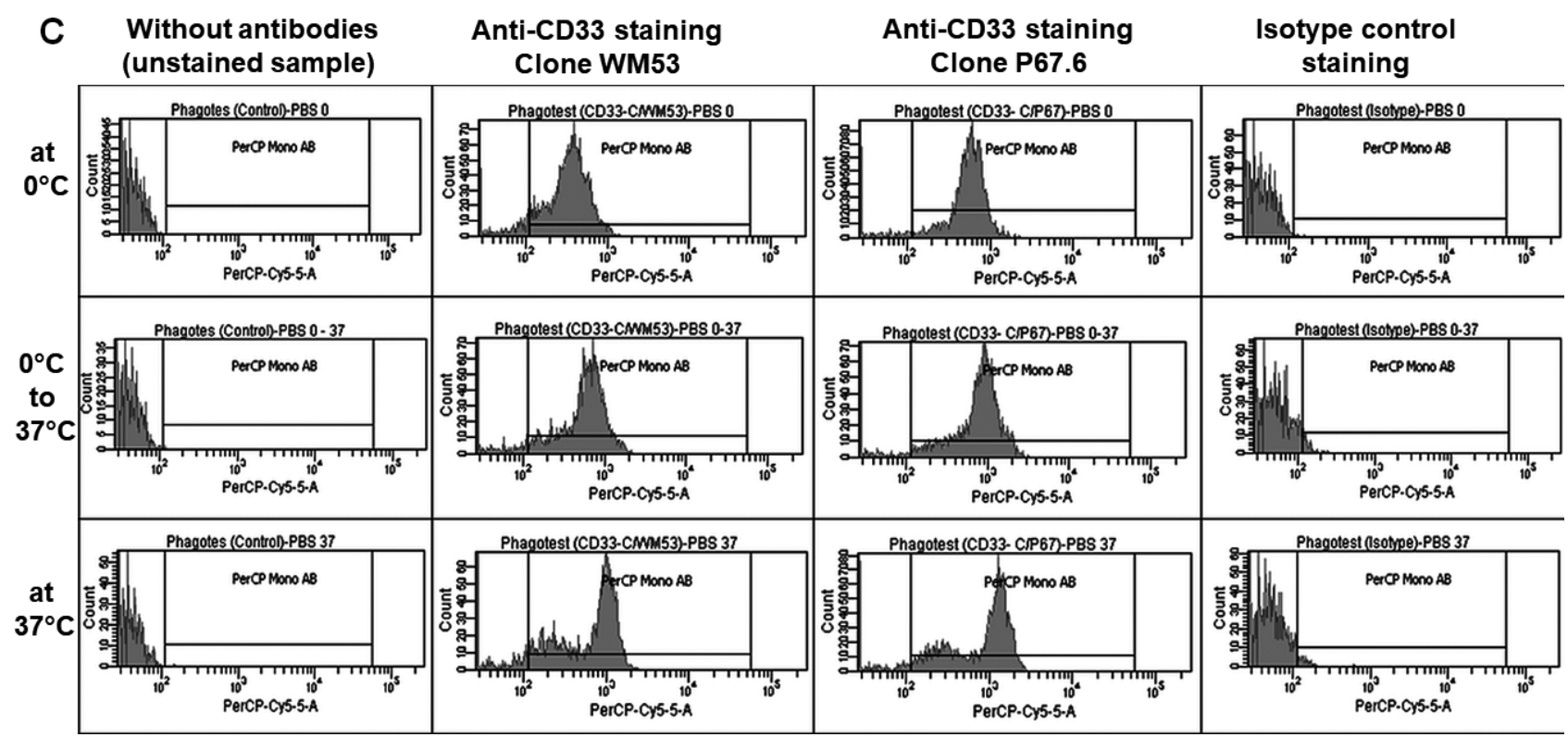

Figure 3. Effect of incubation temperature and phagocytosis on $\mathrm{CD} 33$ expression on monocytes. Cells were chilled at $0^{\circ} \mathrm{C}$, warmed up from $0^{\circ} \mathrm{C}$ to $37^{\circ} \mathrm{C}$, or kept throughout at $37^{\circ} \mathrm{C}$ in the presence of $E$. coli. A. The bar graphs show the percentage of relative median fluorescence intensity (RFI) of CD33 expression $(n=6)$. Three populations of monocytes were assessed for expression, cells chilled at $0^{\circ} \mathrm{C}$, those warmed from $0^{\circ} \mathrm{C}$ to $37^{\circ} \mathrm{C}$, cells held throughout at $37^{\circ} \mathrm{C}$ without stimulation (solid bar) or with E. coli stimulation (open bar). Each bar represents the mean $\pm \mathrm{SD}$, and asterisks indicate the significance of differences versus control $\left({ }^{*} p<0.1 ;{ }^{* * *} p<0.0001\right)$. B. Flow cytometry analysis of CD33 fluorescence intensity (grey area, control; gravy line, monocytes chilled at $0^{\circ} \mathrm{C}$; black line, monocytes chilled at $0^{\circ} \mathrm{C}$, warmed up from $0^{\circ} \mathrm{C}$ to $37^{\circ} \mathrm{C}$; dash line, monocytes held through-out at $37^{\circ} \mathrm{C}$ ). C. Flow cytometry analysis of monocytes without staining, stained with two different clones $\mathrm{CD} 33$, and isotype control chilled at $0^{\circ} \mathrm{C}$, warmed up from $0^{\circ} \mathrm{C}$ to $37^{\circ} \mathrm{C}$ and held at $37^{\circ} \mathrm{C}$. No significant differences between the two clones WM53 and P67.6 were found. 
Table 1. Percentages of phagocytizing monocytes and granulocytes and mean fluorescence intensity upon Fluorescein isothiocyanate (FITC)-labeled E. coli treatment from healthy donors $(n=6)$

\begin{tabular}{lcc}
\hline Type of cells incubated & Phagocytic activity (\%) & $\begin{array}{c}\text { Mean fluorescence intensity } \\
\text { in FITC channel }\end{array}$ \\
\hline \multicolumn{1}{c}{ Monocytes } & & \\
\hline Chilling at $0^{\circ} \mathrm{C}$ & $3.88 \pm 3.21$ & $15.35 \pm 5.1$ \\
Warming up from $0^{\circ} \mathrm{C}$ to $37^{\circ} \mathrm{C}$ & $84.25 \pm 4.97$ & $3764 \pm 1323.3$ \\
Holding throughout at $37^{\circ} \mathrm{C}$ & $78.63 \pm 5.05$ & $3907 \pm 1593.4$ \\
\hline$\quad$ Granulocytes & $3.55 \pm 6.76$ & $19.8 \pm 8.58$ \\
\hline Chilling at $0^{\circ} \mathrm{C}$ & $97 \pm 1.54$ & $6241.17 \pm 1866.67$ \\
Warming up from $0^{\circ} \mathrm{C}$ to $37^{\circ} \mathrm{C}$ & $95.45 \pm 6.23$ & $7027 \pm 2775.8$ \\
\hline Holding throughout at $37^{\circ} \mathrm{C}$ &
\end{tabular}

granulocytes and mean fluorescence intensity upon FITClabeled E. coli treatment from healthy donors is given in Table 1. After incubation with FITC-labeled E. coli a strong increase in both percentages of phagocytosis and mean fluorescence intensity was observed, confirming the ability of monocytes and granulocytes to perform phagocytosis. The fluorescence signal of the phagocytosis activated by FITC-labeled E. coli was significantly increased in the FITCA channel of the monocyte (Fig. 4A) and granulocyte (Fig. 4B) population.

Phagocytosis of $E$. coli induced a significant increase in monocyte expression of CD33 of cells maintained at $37^{\circ} \mathrm{C}$, or cooled to $0^{\circ} \mathrm{C}$ and subsequently warmed to $37^{\circ} \mathrm{C}$ in comparison with the reference population of cells held at $0^{\circ} \mathrm{C}$ which did not phagocytose E. coli (Fig. 3B).
A

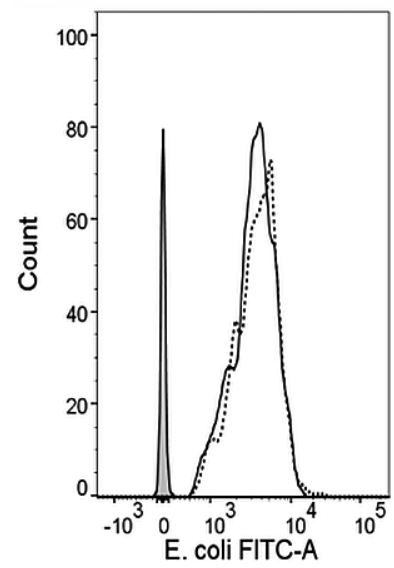

B

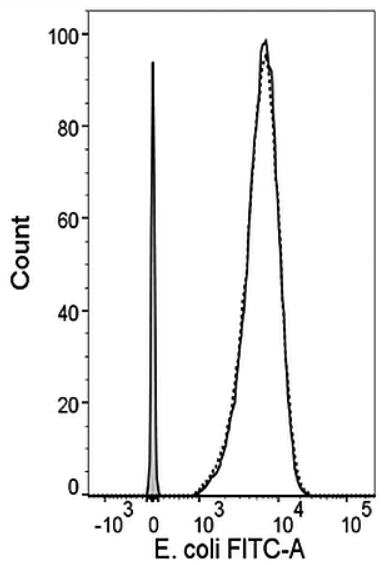

Figure 4. Flow cytometry histograms of the phagocytosis activated by Fluorescein isothiocyanate (FITC)-labeled E. coli in the FITC-A channel of the monocyte $(\mathbf{A})$ and granulocyte $(\mathbf{B})$ population (grey area, chilled at $0^{\circ} \mathrm{C}$; black line, chilled at $0^{\circ} \mathrm{C}$, warmed up from $0^{\circ} \mathrm{C}$ to $37^{\circ} \mathrm{C}$; dash line, held through-out at $37^{\circ} \mathrm{C}$ ).
The results clearly show that together with temperature, phagocytosis has an augmented effect on the expression of CD33. Monocytes held permanently at $37^{\circ} \mathrm{C}$ and incubated with $E$. coli up-regulate the expression of CD33 during phagocytosis in contrast to cells chilled throughout at $0^{\circ} \mathrm{C}$. An additional large increment of CD33 expression occurs when the cells interact with E. coli (Fig. 3A, open bars).

\section{Internalisation of CD33 during phagocytosis}

The influence of phagocytosis was further investigated comparing the CD33 staining in samples where the antibody was applied after stopping the phagocytosis of E. coli (shockcooling at $0^{\circ} \mathrm{C}$ ) with the staining of samples where the antibody was added before phagocytosis activation (warming up to $37^{\circ} \mathrm{C}$ ). In parallel to the quantitative determination of CD33 expressing monocytes by flow cytometry, we studied also the distribution of fluorescence in the cells by CLSM.

Double staining with FITC-labeled Anti-CD14 and PerCP-Cy5-5-A-labeled Anti-CD33 does not allow the use of FITC-labeled E.coli. Therefore the ability of monocytes to perform phagocytosis was tested for each donor in parallel applying the standard procedure of FITC-labeled E. coli (Fig. 5A). Interestingly, by performing double staining, we found that in monocytes the CD14 co-localised with CD33. It can be seen that the monocytes stained after stopping the phagocytosis exhibit a relatively weak fluorescence signal with a distribution mainly on the cell surface (Fig. 5B). In contrast, the samples stained before adding E. coli, the fluorescence signal was significantly higher and fluorescence was observed by microscopy not only on the surface but also inside the cells (Fig. 5C).

The flow cytometry measurements of the blood samples activated for phagocytosis with E. coli showed a slightly enhanced fluorescence signal in the PerCP-Cy5.5 channel of the granulocyte population. Fluorescence from CD33-positive granulocytes could only be detected when anti-CD33 was added before performing phagocytosis in 
contrast to the samples where the staining was performed after stopping phagocytosis (Fig. 6B). Since this population was also clearly negative for staining with anti-CD33 without E.coli stimulation, a certain non-specific binding of the PerCP-Cy5.5-stained CD33 antibody on the opsonized E. coli was assumed. To confirm this, we incubated the opsonized unlabeled E. coli used for the activation of phagocytosis with the PerCP-Cy5.5-anti-CD33 and measured the fluorescence signal of the bacteria in the PerCP-Cy5.5 channel with the same settings as for the cells (Fig. 6A). The obtained fluorescence signal was similar to the signal measured in the PerCP-Cy5.5 for granulocytes stained before phagocytosis confirming that this signals is due to the engulfed bacteria with some antibody bound on them. In contrast, the fluorescence signal of the monocyte population is at least one order of magnitude higher in the same sample (Fig. 6C).

\section{Discussion}

The expression of CD surface antigens may change in response to several conditions in varying degrees. The ex- pression of CD33 has long been recognised as a monocyte lineage marker (Terstappen et al. 1990), which helps to detect monocytes by flow cytometry.

Our results have shown that the RFI of CD33-positive monocytes which had been first cooled and then rewarmed was up-regulated compared with those held throughout at $0^{\circ} \mathrm{C}$, but not significantly different from those handled throughout at $37^{\circ} \mathrm{C}$. To our knowledge, the effect of temperature on the expression levels of CD33 had not been evaluated yet. It has been previously shown that warming of neutrophils from 0 to $37^{\circ} \mathrm{C}$ (Berger et al. 1984), or of neutrophils or monocytes from 4 to $20^{\circ} \mathrm{C}$ (Lundahl et al. 1995; Jämsä et al. 2011), or of monocytes from 4 to $37^{\circ} \mathrm{C}$ (Fearon and Collins 1983; Miller et al. 1987 ) as well as maintaining throughout at $37^{\circ} \mathrm{C}$ (Jämsä et al. 2011) strongly up-regulates antigen surfaces, but holding throughout at $4^{\circ} \mathrm{C}$ the changes during storage are lower. Our results are in agreement with these findings and show that monocytes undergo similar changes. The molecular mechanism underlying up-regulation are still unclear. One possibility is that the rapid increase in surface presentation of CD33 on stimulated monocytes may be

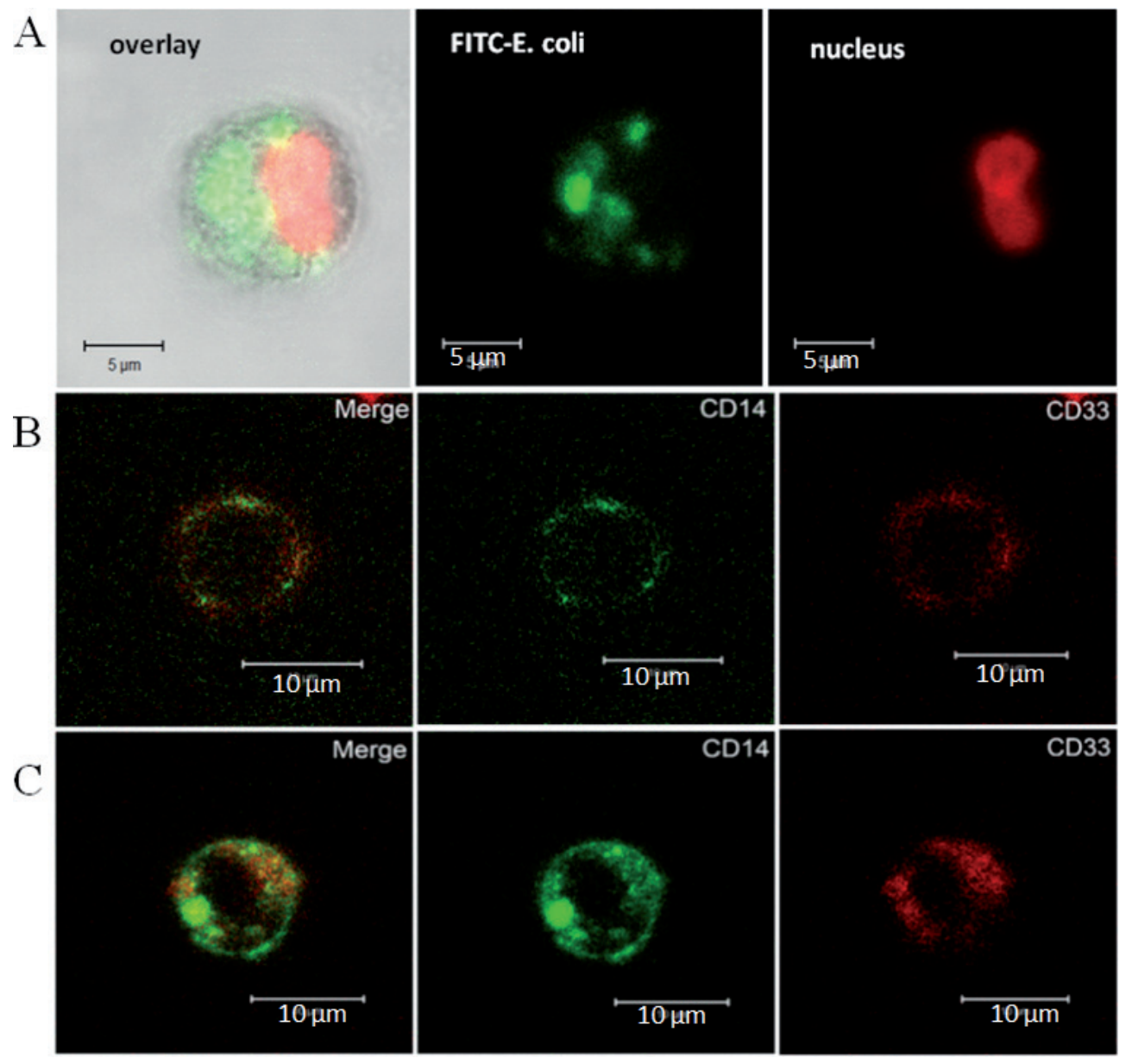

Figure 5. Confocal laser scanning microscopy (CLSM) images of monocytes phagocytosed E. coli. A. Phagocytosis of Fluorescein isothiocyanate (FITC)labeled E. coli, staining of the nucleus of monocytes with propidium iodide (fluorescence mode and overlay micrographs). B. The cells were stained at $0^{\circ} \mathrm{C}$ with both Alexa Fluor 488 antiCD14 and PerCP/Cy5.5 anti-CD33 after performing phagocytosis of non-labeled E. coli. C. The cells were first incubated with both Alexa Fluor 488 anti- CD14 and PerCP/Cy5.5 anti-CD33 for $30 \mathrm{~min}$ at $37^{\circ} \mathrm{C}$ and then with non-labeled E. coli at $37^{\circ} \mathrm{C}$, which allowed to internalise antibody-bound CD14 and CD33. The monocytes phagocytosed E. coli, which results in intracellular fluorescence. Co-localisation of CD14 and CD33 staining was detected in yellow. 

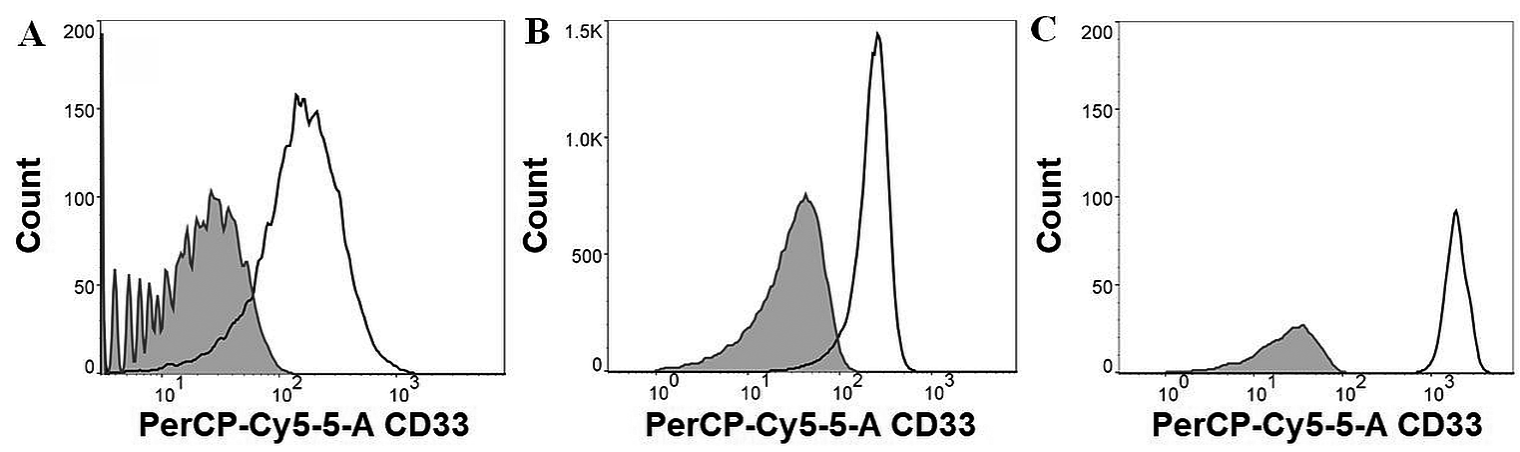

Figure 6. Flow cytometry histograms. A. Opsonized E. coli (grey area) and opsonized E. coli incubated with PerCP-Cy5.5-anti-CD33 at $37^{\circ} \mathrm{C}$ (black line). Granulocytes (B) and monocytes (C) in samples stained with PerCP-Cy5.5-anti-CD33 after performing phagocytosis (grey area), and samples incubated with PerCP-Cy5.5-anti-CD33 before stimulation with non-labelled E. coli at $37^{\circ} \mathrm{C}$ (black line). The $y$-axis value varies depending on the number of cell count.

caused by a translocation of intracellular pool to the cell surface (Siddiqui et al. 2017). It has been reported that the stimulation of LPS results in increased surface expression of CD11b, and CD35 on monocytes, suggesting that these rapid changes may be caused by the inflammatory response (Furebring et al. 2004). In our study, an increase in CD33 expression upon E. coli stimulation was found. Therefore, up-regulation in CD33 may be involved in the inflammatory response, which has been shown to follow the initial systemic pro-inflammatory reaction. CD33 has a high expression on monocyte surface as well as in an internal compartment after stimulation of formylated peptides (fMLP), a bacterial-derived peptide. This could affect the expression of CD33 on the cell surface in response to an inflammatory stimulus (Siddiqui et al. 2017). It is also found that the high antigen induction on the cell surface upon E. coli activation may imply the preformed intracellular pool of surface antigen which was rapidly translocated to the surface upon activation of these cells (Siddiqui et al. 2017). However, how LPS-elicited cell signaling regulates CD33 surface expression is not clear.

The results presented here are in contradiction with previous studies which have published that down-regulation of CD33 expression was observed when monocytes were activated by LPS (Lajaunias et al. 2005; Siddiqui et al. 2017). However, LPS is only one component of the gramnegative bacterial cell wall. Our work was performed with opsonized E. coli which presents a cellular pathogen. The immune system activation and subsequent responses to LPS and E. coli may therefore differ. Another observation, in our experiments, CD33 expression increases considerably within a very short time after contact with bacteria. This is in disagreement with the previously reported results, where the incubation time of LPS was up to $2 \mathrm{~h}$ (Lajaunias et al. 2005; Siddiqui et al. 2017). It appears that a longer time period is required to change the CD33 expression profiles by LPS. Based on the raising level of CD33 expression after exposure to E. coli, revealed significantly altered expression levels in monocytes might be a key element for diagnosis of septic shock. However, the outcomes should be further verified by higher number of blood samples from healthy donors and sepsis patients.

It has been shown that the engagement of both surface CD33 antigen and anti-CD33 antibody, induces receptormediated endocytosis (Walter et al. 2008b), resulting in CD33 internalisation of the antigen/antibody complex into the cells (Audran et al. 1995). This process may reduce the CD33 presented on the cell surface, but it is continuously re-expressed (Van Der Velden et al. 2001). The mechanism of action indicated that the presence of ITIM in the intracellular domain of CD33 is critical for the antibodymediated CD33 internalisation (Walter et al. 2008a, 2012). Intracellular trafficking of CD33 shows that it undergoes endocytosis via clathrin-mediated uptake and further traffics to endosomes and processes in lysosomes (Walter et al. 2012). Moreover, phosphorylation-dependent ubiquitylation of CD33 decreased the cell surface expression and increased the rate of CD33 internalisation (Walter et al. 2008). As a Siglec family member, CD33 has lectin-like recognition molecules which is one of the pattern-recognition receptors (PRRs) (Vasta 2009). These receptors recognise pathogen-associated molecular patterns (PAMPs) from microbial pathogens in the first step of phagocytic process. An immune response is then triggered when PAMPs are recognised. There are some studies mentioned that the treatment of monocytes with anti-CD33 antibodies induced the production of pro-inflammatory cytokines (IL-1 $\beta$, IL-8 and TNF- $\alpha$ ) (Lajaunias et al. 2005) including recruited the tyrosine phosphatase SHP-1 and SHP-2 (Taylor et al. 1999; Paul et al. 2000) and resulted in down-regulated CD64- 
induced calcium influx (Ulyanova et al. 1999; Paul et al. 2000). Taken together, our findings may imply that CD33 could play an associate or even a crucial role in phagocytosis of microbial pathogens.

In conclusion, this study shows that the expression of CD33 on monocytes is influenced by various stimuli such as temperature as well as pathogen. Therefore, excessive processing temperatures and the presence of $E$. coli should be taking into account when analysing leukocyte surface antigens. Further studies are required to elucidate the particular mechanisms of CD33 expression and its impact to the immune system.

Acknowledements. This work was supported by PIRSESGA-2013-612673 and Thai-German S\&T Cooperation 01DP17024. N.S. and C.K. hold an academic development scholarship from the University of Phayao and W.K. from Payap University.

\section{References}

Andrew RG, Torok-Storb B, Bernstein ID (1983): Myeloid-associated differentiation antigens on stem cells and their progeny identified by monoclonal antibodies. Blood 62, 124-132

Audran R, Drenou B, Wittke F, Gaudin A, Lesimple T, Toujas L (1995): Internalization of human macrophage surface antigens induced by monoclonal antibodies. J. Immunol. Methods 188, 147-154

https://doi.org/10.1016/0022-1759(95)00213-8

Berger M, O‘Shea J, Cross AS, Folks TM, Chused TM, Brown EJ, Frank MM (1984): Human neutrophils increase expression of C3bi as well as C3b receptors upon activation. J. Clin. Invest. 74, 1566-1571 https://doi.org/10.1172/JCI111572

Cowan AJ, Laszlo GS, Estey EH, Walter RB (2013): Antibodybased therapy of acute myeloid leukemia with gemtuzumab ozogamicin. Front. Biosci. 18, 1311-1334

https://doi.org/10.2741/4181

Crocker PR, Redelinghuys P (2008): Siglecs as positive and negative regulators of the immune system. Biochem. Soc. Trans. 36, $1467-1471$ https://doi.org/10.1042/BST0361467

Fearon D, Collins L (1983): Increased expression of C3b receptors on polymorphonuclear leukocytes induced by chemotactic factors and by purification procedures. J. Immunol. 130, 370-375

Ferlazzo G, Spaggiari GM, Semino C, Melioli G, Moretta L (2000): Engagement of CD33 surface molecules prevents the generation of dendritic cells from both monocytes and CD34+ myeloid precursors. Eur. J. Immunol. 30, 827-833

https://doi.org/10.1002/1521-4141(200003)30:3<827::AID-IMMU827>3.0.CO;2-1

Forsyth KD, Levinsky RJ (1990): Preparative procedures of cooling and re-warming increase leukocyte integrin expression and function on neutrophils. J. Immunol. Methods 128, 159-163 https://doi.org/10.1016/0022-1759(90)90206-B
Freeman SD, Kelm S, Barber EK, Crocker PR (1995): Characterization of CD33 as a new member of the sialoadhesin family of cellular interaction molecules. Blood 85, 2005-2012

Furebring M, Håkansson L, Venge P, Sjölin J (2004): Differential expression of the $\mathrm{C} 5 \mathrm{a}$ receptor and complement receptors 1 and 3 after LPS stimulation of neutrophils and monocytes. Scand. J. Immunol. 60, 494-499 https://doi.org/10.1111/j.0300-9475.2004.01499.x

Golay J, Zaffaroni L, Vaccari T, Lazzari M, Borleri GM, Bernasconi S, Tedesco F, Rambaldi A, Morgan B (2000): Biologic response of B lymphoma cells to anti-CD20 monoclonal antibody rituximab in vitro: CD55 and CD59 regulate complement-mediated cell lysis. Blood 95, 3900-3908

Hooli B, Tanzi RE (2016): The genetic basis of Alzheimer's disease: findings from genome-wide studies. In: Genomics, Circuits, and Pathways in Clinical Neuropsychiatry. (Eds. T Lehner, B Miller and M State), pp. 547-571, Academic Press, San Diego https://doi.org/10.1016/B978-0-12-800105-9.00034-2

Jämsä J, Huotari V, Savolaine, ER, Syrjälä H, Ala-Kokko T (2011): Analysis of the temperature affects on leukocyte surface antigen expression. J. Clin. Lab. Anal. 25, 118-125 https://doi.org/10.1002/jcla.20444

Jiang T, Yu JT, Hu N, Tan MS, Zhu XC, Tan L (2014): CD33 in alzheimer's disease. Mol. Neurobiol. 49, 529-535 https://doi.org/10.1007/s12035-013-8536-1

Jorgensen PF, Wang JE, Almlof M, Thiemermann C, Foster SJ, Solberg R, Aasen AO (2001): Peptidoglycan and lipoteichoic acid modify monocyte phenotype in human whole blood. Clin. Vaccine Immunol. 8, 515-521 https://doi.org/10.1128/CDLI.8.3.515-521.2001

Krupka C, Kufer P, Kischel R, Zugmaier G, Bögeholz J, Köhnke T, Lichtenegger FS, Schneider S, Metzeler KH, Fiegl M, et al. (2014). CD33 target validation and sustained depletion of AML blasts in long-term cultures by the bispecific T-cell-engaging antibody AMG 330. Blood 123, 356-365 https://doi.org/10.1182/blood-2013-08-523548

Lajaunias F, Dayer JM, Chizzolini C (2005): Constitutive repressor activity of CD33 on human monocytes requires sialic acid recognition and phosphoinositide 3-kinase-mediated intracellular signaling. Eur. J. Immunol. 35, 243-251

https://doi.org/10.1002/eji.200425273

Laszlo GS, Estey EH, Walter RB (2014a): The past and future of CD33 as therapeutic target in acute myeloid leukemia. Blood Rev. 28, 143-153 https://doi.org/10.1016/j.blre.2014.04.001

Laszlo GS., Gudgeon CJ, Harrington KH, Dell‘Aringa J, Newhall KJ, Means GD, Sinclair AM, Kischel R, Frankel SR, Walter RB (2014b): Cellular determinants for preclinical activity of a novel CD33/CD3 bispecific T-cell engager (BiTE) antibody, AMG 330, against human AML. Blood 123, 554-561 https://doi.org/10.1182/blood-2013-09-527044

Lundahl J, Halldén G, Hallgren M, Sköld CM, Hed J (1995): Altered expression of CD11b/CD18 and CD62L on human monocytes after cell preparation procedures. J. Immunol. Methods 180, 93-100 https://doi.org/10.1016/0022-1759(94)00303-E

Miller LJ, Bainton DF, Borregaard N, Springer TA (1987): Stimulated mobilization of monocyte Mac-1 and p150,95 adhesion 
proteins from an intracellular vesicular compartment to the cell surface. J. Clin. Invest. 80, 535-544

https://doi.org/10.1172/JCI113102

Paul SP, Taylor LS, Stansbury EK, McVicar DW (2000): Myeloid specific human CD33 is an inhibitory receptor with differential ITIM function in recruiting the phosphatases SHP-1 and SHP2. Blood 96, 483-490

Repo H, Jansson SE, Leirisalo-Repo M (1995): Anticoagulant selection influences flow cytometric determination of CD11b upregulation in vivo and ex vivo. J. Immunol. Methods 185, 65-79 https://doi.org/10.1016/0022-1759(95)00105-J

Sakamoto K, Ono T, Nakamura Y, Harada H, Nakashima T (2009): Expression of cluster of differentiation 9 glycoprotein in benign and malignant parotid gland tumours. J. Laryngol. Otol. 31, 58-63 https://doi.org/10.1017/S0022215109005106

Siddiqui SS, Springer SA, Verhagen A, Sundaramurthy V, AlissonSilva F, Jiang W, Ghosh P, Varki A (2017): The Alzheimer's disease-protective CD33 splice variant mediates adaptive loss of function via diversion to an intracellular pool. J. Biol. Chem. 292, 15312-15320 https://doi.org/10.1074/jbc.M117.799346

Stibenz D, Buhrer C (1994): Down-regulation of L-selectin surface expression by various leukocyte isolation procedures. Scand. J. Immunol. 39, 59-63 https://doi.org/10.1111/j.1365-3083.1994.tb03340.x

Taylor VC, Buckley CD, Douglas M, Cody AJ, Simmons DL, Freeman SD (1999): The myeloid-specific sialic acid-binding receptor, CD33, associates with the protein-tyrosine phosphatases, SHP-1 and SHP-2. J. Biol. Chem. 274, 11505-11512 https://doi.org/10.1074/jbc.274.17.11505

Terstappen LWMM, Hollander Z, Meiners H, Loken MR (1990): Quantitative comparison lineages of mature of myeloid peripheral antigens on five lineages of mature peripheral blood cells. J. Leukoc. Biol. 48, 138-148 https://doi.org/10.1002/jlb.48.2.138

Tölle A, Abdallah Z, Jung K, Bäumler H (2010): Measurement conditions for flow cytometry analyses of cell lines from urological carcinomas. J. Fluoresc. 20, 779-786 https://doi.org/10.1007/s10895-010-0621-5

Ulyanova T, Blasioli J, Woodford-Thomas TA, Thomas ML (1999): The sialoadhesin CD33 is a myeloid-specific inhibitory receptor. Eur. J. Immunol. 29, 3440-3449 https://doi.org/10.1002/(SICI)1521-4141(199911)29:11<3440::AID-IMMU3440 >3.3.CO;2-3

Van Der Velden VHJ, Te Marvelde JG, Hoogeveen PG, Bernstein ID, Houtsmuller AB, Berger MS, Van Dongen JJM (2001): Targeting of the CD33-calicheamicin immunoconjugate Mylotarg (CMA-676) in acute myeloid leukemia: in vivo and in vitro saturation and internalization by leukemic and normal myeloid cells. Blood 97, 3197-3204

https://doi.org/10.1182/blood.V97.10.3197

Vasta GR (2009): Roles of galectins in infection. Nat. Rev. Microbiol. 7, 424-438 https://doi.org/10.1038/nrmicro2146

Walter RB, Häusermann P, Raden BW, Teckchandani AM, Kamikura DM, Bernstein ID, Cooper JA (2008a): Phosphorylated ITIMs enable ubiquitylation of an inhibitory cell surface receptor. Traffic 9, 267-279 https://doi.org/10.1111/j.1600-0854.2007.00682.x

Walter RB, Raden BW, Zeng R, Häusermann P, Bernstein ID, Cooper JA (2008b): ITIM-dependent endocytosis of CD33related Siglecs: role of intracellular domain, tyrosine phosphorylation, and the tyrosine phosphatases, Shp1 and Shp2. J. Leukoc. Biol. 83, 200-211 https://doi.org/10.1189/jlb.0607388

Walter RB, Raden BW, Kamikura DM, Cooper JA, Bernstein ID, Dc W, Walter, RB, Raden BW, Kamikura DM, Cooper JABernstein ID (2012): Influence of CD33 expression levels and ITIM-dependent internalization on gemtuzumab ozogamicininduced cytotoxicity. Neoplasia 105, 1295-1302 https://doi.org/10.1182/blood-2004-07-2784

Woolfson A, Ellmark P, Chrisp JS, Scott MA, Christopherson RI (2006): The application of CD antigen proteomics to pharmacogenomics. Pharmacogenomics 7, 759-771 https://doi.org/10.2217/14622416.7.5.759

Youssef PP, Mantzioris BX, Roberts-Thomson PJ, Ahern MJ, Smith MD (1995): Effects of ex vivo manipulation on the expression of cell adhesion molecules on neutrophils. J. Immunol. Methods 186, 217-224 https://doi.org/10.1016/0022-1759(95)00146-2

Zhang LX, Ye ., Chen YB, Peng HL, Chen X, Liu, Jiang AG, Huang JX (2013): The effect of CD33 expression on inflammatory response in chronic obstructive pulmonary disease. Immunol. Invest. 42, 701-710 https://doi.org/10.3109/08820139.2013.806542

Zhao L, Kaewprayoon W, Zhou H, Georgieva R, Bäumler H (2017): $\mathrm{RBC}$ aggregation in dextran solutions can be measured by flow cytometry. Clin. Hemorheol. Microcirc. 65, 93-101 https://doi.org/10.3233/CH-15121

Zola H, Swart B, Banham A, Barry S, Beare A, Bensussan A, Boumsell LD, Buckley C, Bühring HJ, Clark G, et al. (2007): CD molecules 2006 - human cell differentiation molecules. J. Immunol. Methods 319, 1-5 https://doi.org/10.1016/j.jim.2006.11.001

Received: February 12, 2019

Final version accepted: May 22, 2019

First published online: August 14, 2019 